\title{
Bench-Scale Flushing Experiments for Remediation of Hg-Contaminated Groundwater
}

\author{
Sung-Wook Jeen \\ Department of Earth and Environmental Sciences and The Earth and Environmental Science System Research Center, \\ Chonbuk National University, Jeonju-si, Jeollabuk-do 561-756, Republic of Korea
}

Correspondence should be addressed to Sung-Wook Jeen; sjeen@jbnu.ac.kr

Received 21 July 2016; Accepted 12 October 2016

Academic Editor: Julie J. M. Mesa

Copyright (C) 2016 Sung-Wook Jeen. This is an open access article distributed under the Creative Commons Attribution License, which permits unrestricted use, distribution, and reproduction in any medium, provided the original work is properly cited.

Bench-scale laboratory column experiments were conducted to determine the desorption characteristics of $\mathrm{Hg}$ in the aquifer material from an area of known elevated $\mathrm{Hg}$ concentrations in groundwater under flushing conditions. The experimental results showed that columns packed with perched aquifer material (PA) showed flushing of $\mathrm{Hg}$, with the general decline of effluent $\mathrm{Hg}$ concentrations over time (from $0.05-0.1 \mathrm{mg} / \mathrm{L}$ in the beginning to $0.0001-0.003 \mathrm{mg} / \mathrm{L}$ at the end of the experiment). Columns with lower aquifer material (LA) showed nondetectable level of effluent $\mathrm{Hg}$ throughout the experiment. Possibility of redissolution/desorption of $\mathrm{Hg}$ after static condition (for the duration of 18 days) was tested, showing only slight rebound of $\mathrm{Hg}$ concentrations after equilibration. The results suggest that removal of up to $20 \%$ of $\mathrm{Hg}$ inventory in the sediment could be achievable for the duration of the experiments (about 10 pore volumes). The results also indicate that the treated water from the water treatment plant was more effective compared to deionized water, probably due to complexing agents contained in the treated water.

\section{Introduction}

Mercury is one of the most toxic contaminants released by gold mining and operation of industrial facilities and elevated mercury concentration down gradient of the mine tailings has been a primary concern for many mining projects [15]. Hg contamination in mining impacting aquatic environments is historically due to gold extraction by amalgamation techniques [6]. Extraction with sodium cyanide has also been widely used and caused mercury contamination in the environment [7]. In the extraction, gold is leached from the ores during gold-cyanide process (GCP) $[8,9]$. In addition to forming gold complexes, cyanide also coordinates other metals such as iron, zinc, copper, and mercury, forming soluble metal-cyano complexes in leachate solution, causing a serious environmental problem [10].

The fate and transport of mercury in the contaminated systems are controlled by the interaction between aqueous speciation and sediment-water partitioning [11-13]. The aqueous speciation of $\mathrm{Hg}$ is strongly affected by chemical conditions such as $\mathrm{pH}$, redox, and concentrations of organic and inorganic ligands $[14,15]$. While environmental impact of mine drainage, which is often acidic and containing elevated levels of mercury, is assessed at some mines, successful remediation measures are not fully implemented [16].

Recent efforts for remediating Hg-contaminated water include methods using zerovalent iron (ZVI) [17-19], elemental $\mathrm{Cu}$ and $\mathrm{S}$, granular activated carbon (GAC), attapulgite clay (ATP) [18], and biochars [20]. However, in situ technologies to remediate $\mathrm{Hg}$-contaminated groundwater yet need to be developed. In this regard, only a few studies have been conducted to investigate the controls on $\mathrm{Hg}$ mobility and leaching persistence originated from mine tailings $[21,22]$.

In this study, bench-scale column flushing experiments were conducted to mitigate elevated dissolved mercury concentrations down gradient from the mine tailings at a gold and silver mine. The flushing experiments evaluated whether injected water can flush redissoved/desorbed $\mathrm{Hg}$ in the aquifer under the ideal conditions in the laboratory, from which determination can be drawn with regard to the actual remedial performance in the field.

Little is known about the geochemical characteristics of the aquifer matrix at the site with respect to adsorption/ desorption properties for contaminants and in particular 
mercury in solution. Understanding these characteristics is integral to developing the most efficient remedial strategy and to constraining the estimates for completion of aquifer remediation. The bench-scale laboratory column experiments were conducted to augment the pilot aquifer flushing test to determine the desorption characteristics of $\mathrm{Hg}$ in the aquifer material from an area of known elevated $\mathrm{Hg}$ concentrations in groundwater. Key objectives of the study were (1) to determine maximum achievable removal of $\mathrm{Hg}$ from aquifer solids using potential flushing water, including water sourced from the water treatment plant, which is located downgradient from the tailings, and deionized water and (2) to determine $\mathrm{Hg}$ desorption behavior in aquifer solids and to determine the potential for postflushing desorption of Hg from aquifer solids.

The experiments were performed in small columns, measured $\mathrm{Hg}$ concentrations overtime, and provided empirical information on the number of pore volumes required for successful flushing. In addition, following initial flushing, columns were permitted to equilibrate and residual $\mathrm{Hg}$ concentrations in pore water were measured to evaluate the potential for postflushing desorption and whether this geochemical process could contribute to unacceptable residual $\mathrm{Hg}$ concentrations in groundwater. The results will help to define the threshold of reasonably achievable remediation of $\mathrm{Hg}$ from the aquifer.

\section{Materials and Methods}

2.1. Sediments and Source Water. The mining of gold and silver ore at the mine site began in early 1990s. The tailings are dry-filtered and placed in an adjacent mountain slope. Cyanide used in the milling process is discharged with the tailings. Typically, the tailings are disposed with a maximum moisture content of $15 \mathrm{wt} . \%$. Although the tailings have low moisture content, monitoring identified an extensive plume of groundwater contaminated with $\mathrm{Hg}$ in the unconfined aquifer. The mercury treatment plant and the planned remedial system site are located approximately $5 \mathrm{~km}$ downgradient from the tailings.

Aquifer materials for filling the columns were collected from the drilled cores at the pilot test remedial system site. Three sediment cores were collected at the site and sent to the laboratory. One core represents perched aquifer sediment and was collected from depth of 17.5 to $18.5 \mathrm{~m}$. This depth of the core contains poorly graded sand and gravel with maximum particle size of $60 \mathrm{~mm}$. Particles are subrounded to rounded and have brownish color with black patches. Sediment has some moisture content and is odorless. Two other cores were from the lower aquifer and represent samples from 35 to $36.5 \mathrm{~m}$ and from 41 to $42.5 \mathrm{~m}$. The core from depth of 35 to $36.5 \mathrm{~m}$ contains soft silty sand and is very wet. The core from depth of 41 to $42.5 \mathrm{~m}$ also contains silt to sandy silt with orange mottling and is moist. These two cores were treated essentially as the same material and thus were mixed together during the column packing. For characterization of the sediments, paste $\mathrm{pH}$, particle size distribution, total organic and inorganic carbons, metals, and total sulfur were analyzed and the results are presented in Table 1. Of note, mercury (Hg) content in sediment samples was $0.196 \mathrm{mg} / \mathrm{kg}$ for perched aquifer material and $0.0287 \mathrm{mg} / \mathrm{kg}$ for lower aquifer material.

A total of 20 liters of treated water from the water treatment plant at the site were sent to the laboratory. The $\mathrm{pH}$, alkalinity, electrical conductivity (EC), total cyanide, and dissolved metals including mercury were analyzed for the received water, as the results presented in Table 2. Deionized water was also used for the experiments to test the performance in comparison to the treated water.

2.2. Column Setup. A total of six flow-through columns were manufactured and the column experiments were conducted simultaneously. Two columns were packed with the sediment from perched aquifer (PA): one received deionized water (DI) and another received treated water from the treatment plant (TW). Three columns were packed with the sediment from lower aquifer (LA). One column received the treated water, while two other columns received deionized water. The latter two columns (LA-DI1 and LA-DI2) were set up as duplicates to test reproducibility of the experiments. The sixth column contained only silica sand (SS) and received deionized water as the influent. It served as a control column.

For all of the columns, except the control column (SSDI), approximately $2.5 \mathrm{~cm}$ of clean silica sand was layered at the influent and effluent ends of the columns to improve the distribution of flow in the columns and to filter coarse solids out of the effluent. Silica sand was washed with $5 \% \mathrm{HNO}_{3}$ solution overnight and then rinsed with plenty of deionized water until $\mathrm{pH}$ is back to normal ( $>\mathrm{pH} 5$ ). The control column was about half filled only with silica sand and thus pore volume was less than other columns. Characteristics of each column are summarized in Table 3.

Each column consisted of a clear acrylic tube, $21.5 \mathrm{~cm}$ length and $15 \mathrm{~cm}$ internal diameter, and was fitted with end plates. Column dimensions have been selected to optimize the flow rate to allow for a low velocity flow representative of typical field conditions in the aquifer sediments and also to accommodate representative volume of aquifer materials.

Aquifer sediments were retrieved from the cores inside a $\mathrm{N}_{2}$ glove bag to minimize disturbance of redox conditions in the sediments. The glove bag was fully inflated with $\mathrm{N}_{2}$ gas and then deflated three times after a core was located inside the bag. Sediments were retrieved under positive pressure of $\mathrm{N}_{2}$ and thus oxygen intrusion was minimized. After all of the sediments were retrieved from the cores, each of aquifer materials (PA or LA) was mixed by hands to homogenize the sediments as much as possible. This was to ensure that sediments in the columns should have representative samples for each aquifer material. Some large particles such as gravel were excluded from the packing materials.

The retrieved sediments (within the glove bag) were relocated into another glove bag. At this point, the column with $\sim 2.5 \mathrm{~cm}$ of silica sand at the bottom was put into the same bag. After that, the outer glove bag was once again purged with $\mathrm{N}_{2}$ gas three times before column packing started. The sediment was packed into the column over the silica sand 
TABLE 1: Characteristics of aquifer materials.

\begin{tabular}{|c|c|c|c|}
\hline Sample & Perched aquifer (PA) & Lower aquifer (LA) & Detection limit \\
\hline pH (1:2 soil : water $)$ & 4.24 & 6.35 & 0.01 \\
\hline \multicolumn{4}{|l|}{ Particle size } \\
\hline$\%$ gravel (>2 mm) & 8.97 & 5.78 & 0.10 \\
\hline$\%$ sand $(2.00 \mathrm{~mm}-1.00 \mathrm{~mm})$ & 18.3 & 14.8 & 0.10 \\
\hline$\%$ sand $(1.00 \mathrm{~mm}-0.50 \mathrm{~mm})$ & 21.9 & 18.3 & 0.10 \\
\hline$\%$ sand $(0.50 \mathrm{~mm}-0.25 \mathrm{~mm})$ & 11.2 & 9.76 & 0.10 \\
\hline$\%$ sand $(0.25 \mathrm{~mm}-0.125 \mathrm{~mm})$ & 10.7 & 10.7 & 0.10 \\
\hline$\%$ sand $(0.125 \mathrm{~mm}-0.063 \mathrm{~mm})$ & 5.23 & 6.86 & 0.10 \\
\hline$\%$ silt $(0.063 \mathrm{~mm}-0.0312 \mathrm{~mm})$ & 7.17 & 8.37 & 0.10 \\
\hline$\%$ silt $(0.0312 \mathrm{~mm}-0.004 \mathrm{~mm})$ & 10.6 & 14.8 & 0.10 \\
\hline$\%$ clay $(<4 \mu \mathrm{m})$ & 6.04 & 10.7 & 0.10 \\
\hline Texture & Sandy loam/loamy sand & Sandy loam & \\
\hline \multicolumn{4}{|l|}{ Organic/inorganic carbon } \\
\hline $\mathrm{CaCO}_{3}$ equivalent (\%) & $<0.80$ & $<0.80$ & 0.80 \\
\hline Inorganic carbon (\%) & $<0.10$ & $<0.10$ & 0.10 \\
\hline Total carbon (\%) & 0.1 & $<0.1$ & 0.1 \\
\hline Total organic carbon (\%) & 0.10 & $<0.10$ & 0.10 \\
\hline \multicolumn{4}{|l|}{ Metals } \\
\hline Aluminum (Al) (mg/kg) & 31900 & 54100 & 50 \\
\hline Antimony (Sb) (mg/kg) & 2.48 & 1.91 & 0.10 \\
\hline Arsenic (As) (mg/kg) & 282 & 178 & 0.050 \\
\hline Barium (Ba) (mg/kg) & 157 & 146 & 0.50 \\
\hline Beryllium (Be) (mg/kg) & 0.61 & 1.34 & 0.20 \\
\hline Bismuth (Bi) (mg/kg) & $<0.20$ & 0.26 & 0.20 \\
\hline Cadmium (Cd) (mg/kg) & 2.07 & 0.227 & 0.050 \\
\hline Calcium (Ca) (mg/kg) & 1060 & 2430 & 50 \\
\hline Chromium (Cr) (mg/kg) & 8.77 & 11.3 & 0.50 \\
\hline Cobalt (Co) $(\mathrm{mg} / \mathrm{kg})$ & 50.1 & 12.8 & 0.10 \\
\hline Copper (Cu) (mg/kg) & 85.9 & 52.9 & 0.50 \\
\hline Iron $(\mathrm{Fe})(\mathrm{mg} / \mathrm{kg})$ & 35000 & 33900 & 50 \\
\hline Lead $(\mathrm{Pb})(\mathrm{mg} / \mathrm{kg})$ & 47.1 & 27.1 & 0.50 \\
\hline Lithium (Li) (mg/kg) & 55.6 & 25.6 & 5.0 \\
\hline Magnesium (Mg) (mg/kg) & 2610 & 3010 & 20 \\
\hline Manganese (Mn) (mg/kg) & 7790 & 2330 & 1.0 \\
\hline Mercury (Hg) (mg/kg) & 0.196 & 0.0287 & 0.0050 \\
\hline Molybdenum (Mo) (mg/kg) & 2.00 & 2.16 & 0.50 \\
\hline Nickel (Ni) (mg/kg) & 13.9 & 8.70 & 0.50 \\
\hline Phosphorus (P) (mg/kg) & 537 & 509 & 50 \\
\hline Potassium (K) (mg/kg) & 1370 & 1520 & 100 \\
\hline Selenium (Se) (mg/kg) & $<0.20$ & $<0.20$ & 0.20 \\
\hline Silver (Ag) (mg/kg) & 0.38 & 0.18 & 0.10 \\
\hline Sodium (Na) (mg/kg) & 270 & 250 & 100 \\
\hline Strontium (Sr) (mg/kg) & 80.1 & 133 & 0.50 \\
\hline Sulfur (S), total (mg/kg) & 1100 & 1400 & 500 \\
\hline Thallium (Tl) (mg/kg) & 2.61 & 0.830 & 0.050 \\
\hline $\operatorname{Tin}(\mathrm{Sn})(\mathrm{mg} / \mathrm{kg})$ & $<2.0$ & $<2.0$ & 2.0 \\
\hline Titanium (Ti) (mg/kg) & 774 & 787 & 1.0 \\
\hline Uranium (U) (mg/kg) & 0.543 & 1.18 & 0.050 \\
\hline Vanadium (V) (mg/kg) & 70.6 & 90.7 & 0.20 \\
\hline Zinc $(\mathrm{Zn})(\mathrm{mg} / \mathrm{kg})$ & 358 & 407 & 1.0 \\
\hline
\end{tabular}


TABLE 2: Composition of the treated water collected from the water treatment plant.

\begin{tabular}{|c|c|c|c|}
\hline Parameter & Unit & Concentration & $\begin{array}{c}\text { Detection } \\
\text { limit }\end{array}$ \\
\hline Alkalinity & $\mathrm{mg} / \mathrm{L}$ as $\mathrm{CaCO}_{3}$ & 14 & 0.10 \\
\hline $\mathrm{pH}$ & - & 3.85 & 0.01 \\
\hline $\begin{array}{l}\text { Electrical } \\
\text { conductivity (EC) }\end{array}$ & $\mu \mathrm{S} / \mathrm{cm}$ & 2950 & 0.10 \\
\hline Total cyanide & $\mathrm{mg} / \mathrm{L}$ & 0.0231 & 0.0050 \\
\hline Aluminum (Al) & $\mathrm{mg} / \mathrm{L}$ & 28.2 & 0.0025 \\
\hline Antimony (Sb) & $\mathrm{mg} / \mathrm{L}$ & $<0.00010$ & 0.00010 \\
\hline Arsenic (As) & $\mathrm{mg} / \mathrm{L}$ & 0.00407 & 0.00010 \\
\hline Barium $(\mathrm{Ba})$ & $\mathrm{mg} / \mathrm{L}$ & 0.00948 & 0.00010 \\
\hline Beryllium (Be) & $\mathrm{mg} / \mathrm{L}$ & 0.0147 & 0.000050 \\
\hline Bismuth (Bi) & $\mathrm{mg} / \mathrm{L}$ & $<0.000025$ & 0.000025 \\
\hline Boron (B) & $\mathrm{mg} / \mathrm{L}$ & 0.917 & 0.025 \\
\hline Cadmium (Cd) & $\mathrm{mg} / \mathrm{L}$ & 0.00692 & 0.000025 \\
\hline Calcium (Ca) & $\mathrm{mg} / \mathrm{L}$ & 432 & 0.10 \\
\hline Chromium (Cr) & $\mathrm{mg} / \mathrm{L}$ & 0.00065 & 0.00050 \\
\hline Cobalt (Co) & $\mathrm{mg} / \mathrm{L}$ & 0.0764 & 0.000025 \\
\hline Copper $(\mathrm{Cu})$ & $\mathrm{mg} / \mathrm{L}$ & 0.213 & 0.00050 \\
\hline Iron $(\mathrm{Fe})$ & $\mathrm{mg} / \mathrm{L}$ & 0.207 & 0.0050 \\
\hline Lead $(\mathrm{Pb})$ & $\mathrm{mg} / \mathrm{L}$ & 0.000065 & 0.000025 \\
\hline Lithium (Li) & $\mathrm{mg} / \mathrm{L}$ & 0.712 & 0.0025 \\
\hline Magnesium (Mg) & $\mathrm{mg} / \mathrm{L}$ & 61.6 & 0.025 \\
\hline Manganese (Mn) & $\mathrm{mg} / \mathrm{L}$ & 16.6 & 0.00025 \\
\hline Mercury (Hg) & $\mathrm{mg} / \mathrm{L}$ & 0.000038 & 0.000010 \\
\hline Molybdenum (Mo) & $\mathrm{mg} / \mathrm{L}$ & $<0.00025$ & 0.00025 \\
\hline Nickel (Ni) & $\mathrm{mg} / \mathrm{L}$ & 0.0430 & 0.00025 \\
\hline Phosphorus (P) & $\mathrm{mg} / \mathrm{L}$ & $<1.5$ & 1.5 \\
\hline Potassium (K) & $\mathrm{mg} / \mathrm{L}$ & 7.22 & 0.25 \\
\hline Selenium (Se) & $\mathrm{mg} / \mathrm{L}$ & 0.00054 & 0.00020 \\
\hline Silicon (Si) & $\mathrm{mg} / \mathrm{L}$ & 47.4 & 0.25 \\
\hline Silver (Ag) & $\mathrm{mg} / \mathrm{L}$ & $<0.000025$ & 0.000025 \\
\hline Sodium $(\mathrm{Na})$ & $\mathrm{mg} / \mathrm{L}$ & 112 & 0.050 \\
\hline Strontium (Sr) & $\mathrm{mg} / \mathrm{L}$ & 1.05 & 0.00025 \\
\hline Thallium (Tl) & $\mathrm{mg} / \mathrm{L}$ & 0.000011 & 0.000010 \\
\hline $\operatorname{Tin}(\mathrm{Sn})$ & $\mathrm{mg} / \mathrm{L}$ & $<0.000050$ & 0.000050 \\
\hline Titanium (Ti) & $\mathrm{mg} / \mathrm{L}$ & $<0.0025$ & 0.0025 \\
\hline Uranium (U) & $\mathrm{mg} / \mathrm{L}$ & 0.00118 & 0.000010 \\
\hline Vanadium (V) & $\mathrm{mg} / \mathrm{L}$ & 0.00041 & 0.00025 \\
\hline Zinc $(\mathrm{Zn})$ & $\mathrm{mg} / \mathrm{L}$ & 10.2 & 0.0025 \\
\hline Zirconium $(\mathrm{Zr})$ & $\mathrm{mg} / \mathrm{L}$ & $<0.00050$ & 0.00050 \\
\hline
\end{tabular}

layer by an increment of about $2.5 \mathrm{~cm}$ at each step, after which the column wall was gently tapped by hand to homogenize the sediment inside the column. This step continued until the column was packed leaving only about $2.5 \mathrm{~cm}$ at the top. The column packing was completed by filling with silica sand to the remaining portion of the column at the top. Once column packing was completed, columns were saturated with deionized water before the desired source solutions for each column were introduced. Column weights were measured at each step of the column packing and saturated pore volume (PV) and porosity were calculated from the column weights before and after saturation (Table 3 ). The column experiments were conducted for a total of 44 days at room temperature.

2.3. Column Operation. Figure 1 shows the schematic of the column experiment. The column experiment was designed so that water enters from the bottom of the column and flows upward discharging from the top of the columns; thus, the bottom of the column is effectively upgradient and the top of the column is downgradient. This was done to ensure consistent and even flow throughout the columns, eliminating the risk of uncontrolled gravity-driven drainage and preferential flow paths.

The nominal residence time in the aquifer layer (excluding $\sim 2.5 \mathrm{~cm}$ layer of silica sand at each end of the column) was calculated with the target flow rate of $400 \mathrm{~mL} /$ day and the average porosity of 0.3 . The actual flow rates in the columns during the experiments were slightly variable, but generally the flow ranged between 350 and $390 \mathrm{~mL} /$ day. This corresponded to $0.40-0.45 \mathrm{PV} /$ day, with an exception of the control column. Because of the smaller pore volume, the control column had the flow rates ranging from 0.62 to $0.67 \mathrm{PV} /$ day. With these flow rates, water velocity through the columns was $6.5-7.3 \mathrm{~cm} /$ day and residence time was between 2.2 and 2.5 days, indicating that residence time for water in each of the columns is quite similar. By end of the experiment, 9.0-9.5 L of source water had flushed through the columns (Figure 2(a)). With respective to the cumulative PV flushed through the columns, approximately $16 \mathrm{PV}$ flowed through the control column (SS-DI) and 10-11 PV flowed through the other columns (Figure 2(b)).

Following the initial flushing for 16 days, columns were allowed to equilibrate for a period of 18 days without the movement of flushing water through the columns. After the equilibration period, flushing of the columns recommenced and samples were immediately collected from the equilibrated aquifer pore water to determine if postflushing desorption had occurred. This equilibration period is indicated by discontinuities between elapsed days of 16 and 17 in the cumulative effluent volumes and cumulative pore volumes in Figure 2.

2.4. Sample Collection and Analysis. A total of 11 samplings were conducted for each of the columns every two to four days during the total operation period of 44 days. Between elapsed days 16 and 17, pumping was stopped for the duration of 18 days to evaluate if $\mathrm{Hg}$ concentration is rebounded due to redissolution/desorption in static conditions; thus, the total elapsed days for the flow-through period, excluding the 18 days of static conditions, were 26 days by the end of the experiment.

For each sampling event, approximately $80 \mathrm{~mL}$ of sample was collected from each of the column effluents $(40 \mathrm{~mL}$ for metals, $15 \mathrm{~mL}$ for total cyanide, and $25 \mathrm{~mL}$ for $\mathrm{pH} /$ 
TABLE 3: Column properties.

\begin{tabular}{|c|c|c|c|c|c|c|}
\hline Column & SS-DI & PA-DI & PA-TW & LA-DI1 & LA-DI2 & LA-TW \\
\hline Sediment & $\begin{array}{l}\text { Silica sand } \\
\text { (SS) }\end{array}$ & $\begin{array}{c}\text { Perched } \\
\text { aquifer (PA) }\end{array}$ & $\begin{array}{c}\text { Perched } \\
\text { aquifer (PA) }\end{array}$ & $\begin{array}{l}\text { Lower aquifer } \\
\text { (LA) }\end{array}$ & $\begin{array}{l}\text { Lower aquifer } \\
\text { (LA) }\end{array}$ & $\begin{array}{l}\text { Lower aquifer } \\
\text { (LA) }\end{array}$ \\
\hline Source water & $\begin{array}{l}\text { Deionized } \\
\text { water (DI) }\end{array}$ & $\begin{array}{l}\text { Deionized } \\
\text { water (DI) }\end{array}$ & $\begin{array}{l}\text { Treated water } \\
\text { (TW) }\end{array}$ & $\begin{array}{l}\text { Deionized } \\
\text { water (DI) }\end{array}$ & $\begin{array}{l}\text { Deionized } \\
\text { water (DI) }\end{array}$ & $\begin{array}{c}\text { Treated water } \\
\text { (TW) }\end{array}$ \\
\hline Mass of sediment (kg) & 3.52 & 5.35 & 5.73 & 5.26 & 5.43 & 5.70 \\
\hline Estimated pore water volume $\left(\mathrm{cm}^{3}\right)$ & $556^{\mathrm{a}}$ & 1000 & 800 & 835 & 835 & 835 \\
\hline Porosity & 0.30 & 0.34 & 0.27 & 0.29 & 0.29 & 0.29 \\
\hline Elapsed days ${ }^{\mathrm{b}}$ & 26 & 26 & 26 & 26 & 26 & 26 \\
\hline Cumulative pore volume (PV) flushed & 16.30 & 10.72 & 10.63 & 10.96 & 10.94 & 10.51 \\
\hline
\end{tabular}

${ }^{\text {a }}$ SS-DI was only half filled with silica sand; thus pore volume is less than other columns.

${ }^{\mathrm{b}}$ Between elapsed days 16 and 17, pumping was stopped for the duration of 18 days. Thus, the total column operation period was $26+18=44$ days.

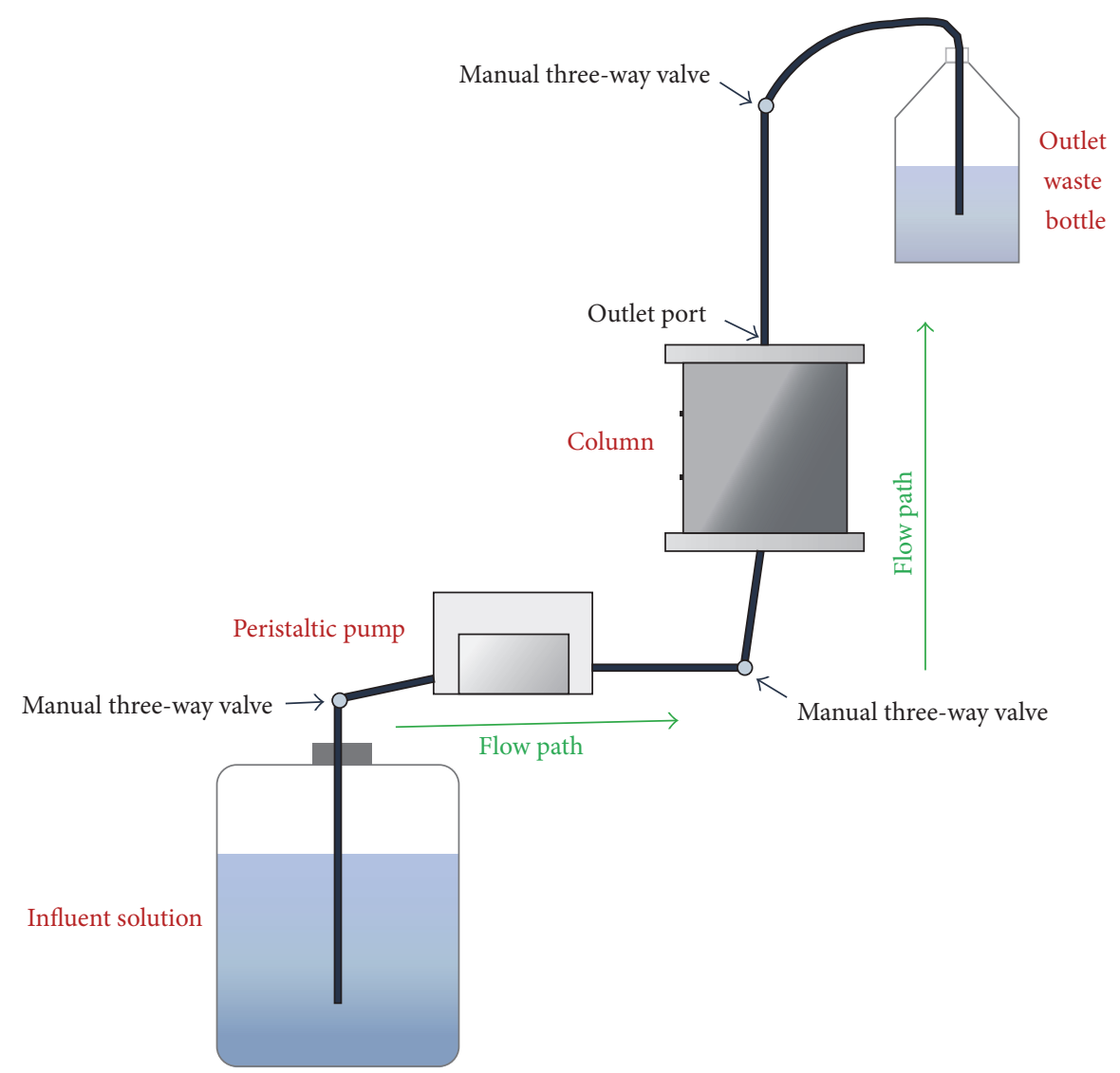

FIGURE 1: Schematic of the column experiment.

alkalinity/EC). To preserve the redox state during sampling, the sampling bottle was purged with nitrogen gas before each of sampling events. Outlet tubing from the sampling bottle was submersed under water to prevent oxygen ingress into the sampling bottle during sampling. Sample was passed through an in-line syringe filter $(0.45 \mu \mathrm{m})$ so that analyses of dissolved components can be done without interference potentially induced by sampling procedures.

Samples for dissolved metals including $\mathrm{Hg}$ were acidified with concentrated, ultrapure nitric acid after filtration.
Samples for total cyanide were prepared by adding $100 \mu \mathrm{L}$ of $6 \mathrm{~N} \mathrm{NaOH}$ to a $15 \mathrm{~mL}$ of filtered sample. Samples for metals and total cyanide analyses were refrigerated immediately after collection and were analyzed using inductively coupled plasma-mass spectrometry (ICP-MS) and colorimetric analysis (ISO 14403:2002), respectively.

$\mathrm{pH}$, alkalinity, and EC were determined immediately after each sampling event. For $\mathrm{pH}$ measurement, a three-point calibration was carried out for the $\mathrm{pH}$ meter each time using $\mathrm{pH}$ 4.01, 7.00, and 10.01 buffers. Total alkalinity was determined by colorimetric titration with $0.01 \mathrm{M}$ hydrochloric acid. EC 


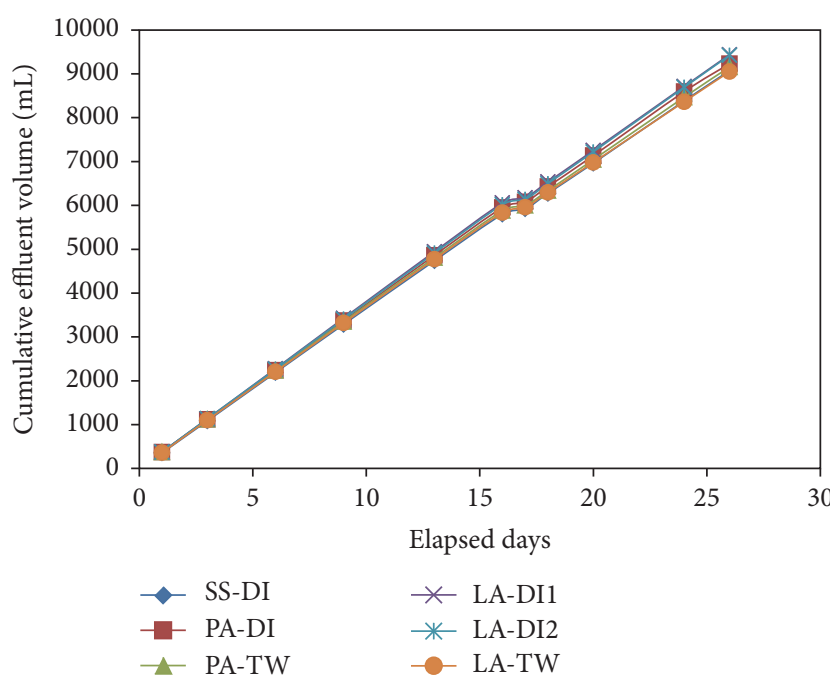

(a)

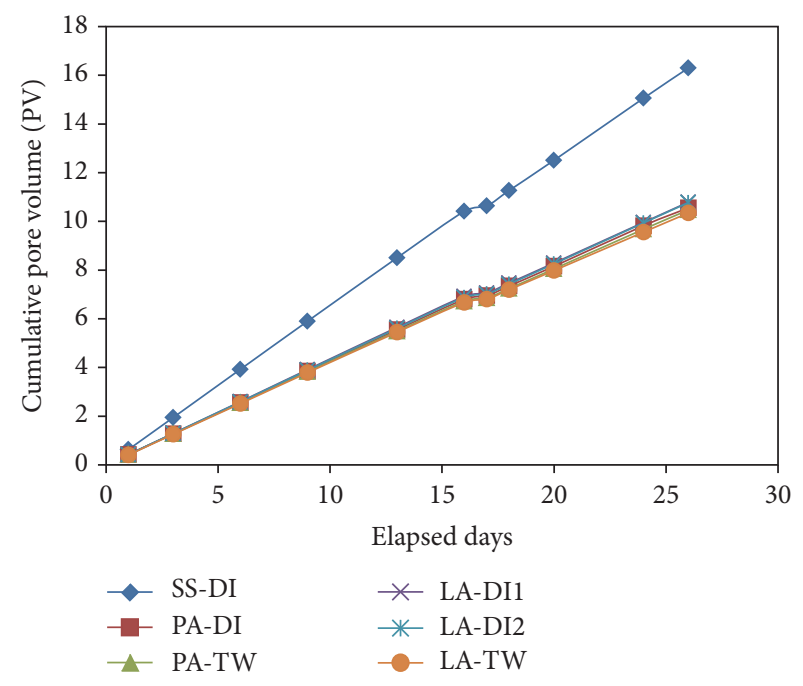

(b)

Figure 2: (a) Cumulative effluent volume (mL) and (b) cumulative pore volume (PV) for each column.

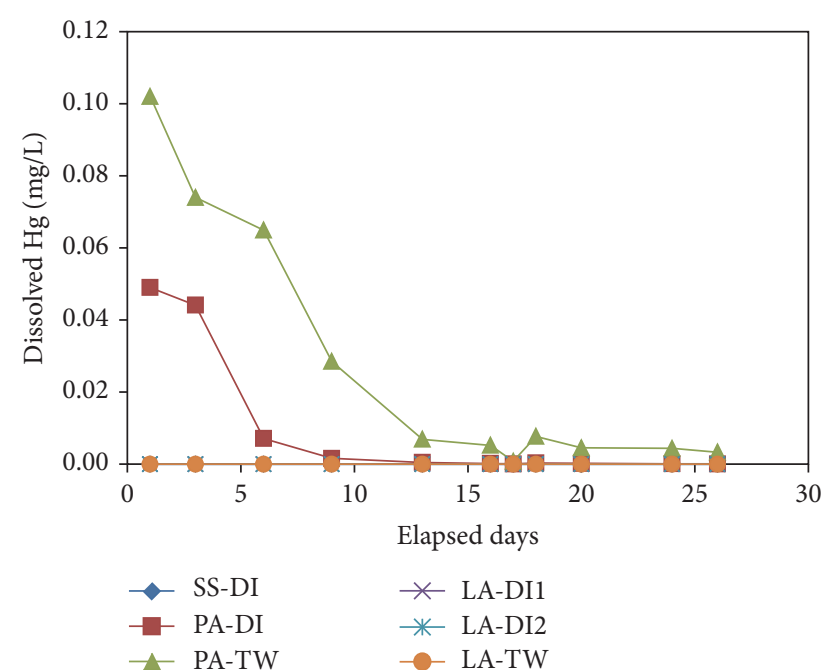

FIGURE 3: Dissolved Hg concentrations measured over time for each column.

was measured by a Thermo Scientific/Orion 5 Star conductivity meter with an Orion $013010 \mathrm{MD}$ conductivity cell after calibration with a $1413 \mu \mathrm{S} / \mathrm{cm}$ conductivity standard solution. Total organic and inorganic carbons, metals, and total sulfur for the sediments were analyzed using gravimetric method [23], ICP-MS, and combustion method (ISO 15178:2000), respectively. Detection limits for the analyses are provided in Tables 1 and 2. Replicate analyses showed little differences.

\section{Results and Discussion}

3.1. Mercury ( $\mathrm{Hg}$ ). Figure 3 shows the dissolved Hg concentrations for each of column effluents measured over time. Elevated concentrations of dissolved $\mathrm{Hg}$ at the effluents were only observed for the columns containing the sediment from perched aquifer (PA). Column effluents from lower aquifer material (LA) showed nondetectable level of dissolved $\mathrm{Hg}$ throughout the column operation the same as the control column (SS-DI). The duplicate columns for LA receiving deionized water (DI) showed the similar behaviors with regard to effluent water chemistry (also for other parameters), suggesting that the sediments were relatively homogeneous between the columns and thus column results are representative at least for the sediments collected in the cores.

The highest dissolved $\mathrm{Hg}$ concentration was $0.102 \mathrm{mg} / \mathrm{L}$ for PA-TW at day 1 (0.43 PV), while the highest concentration for PA-DI was $0.049 \mathrm{mg} / \mathrm{L}$ at day $1(0.43 \mathrm{PV})$. The difference in $\mathrm{Hg}$ concentrations for the two columns is believed to be due to different complexing abilities of the influent water, primarily represented by total cyanide concentrations (see Figure 4). It is also possible that other complexing agents in the treated water, such as dissolved organic matter (DOM), are responsible for the enhanced $\mathrm{Hg}$ recovery. $\mathrm{Hg}$ forms strong complexes with organic matter due to its high binding affinity $[24,25]$. Also, common complexing ligands, such as chloride and sulfate, can affect the sorption of $\mathrm{Hg}$ on the mineral surfaces [26]. Chloride can form aqueous $\mathrm{HgCl}_{2}$ and $\mathrm{Hg}_{2} \mathrm{Cl}_{2}$ complexes reducing sorption of $\mathrm{Hg}$. Concentrations of dissolved organic carbon (DOC) and chloride at the effluent water were not measured in this study; however, total organic carbon content in the sediment is higher in the PA than LA (Table 1) and chloride concentration up to $170 \mathrm{mg} / \mathrm{L}$ is reported in the downgradient aquifer from the field monitoring data, partially supporting this possibility.

The dissolved $\mathrm{Hg}$ concentrations at the effluents continuously decreased to $3.33 \mu \mathrm{g} / \mathrm{L}$ for PA-TW and $0.079 \mu \mathrm{g} / \mathrm{L}$ for PA-DI by the end of the experiments. Most of the decline was observed before day 13 (5.58 PV) for PA-TW and day 9 (3.91 PV) for PA-DI. The experimental results indicate that flushing of aquifer by injection of water may achieve decreased level of $\mathrm{Hg}$ in the field. 
TABLE 4: Hg removal efficiency by flushing.

\begin{tabular}{|c|c|c|c|c|c|}
\hline Column & PA-DI & PA-TW & LA-DI1 & LA-DI2 & LA-TW \\
\hline Hg in sediment $(\mathrm{mg})$ & 1.048 & 1.123 & 0.151 & 0.156 & 0.163 \\
\hline Maximum concentration expected in pore water $(\mathrm{mg} / \mathrm{L})$ & 1.05 & 1.40 & 0.18 & 0.19 & 0.20 \\
\hline Hg removal by flushing (mg) & 0.063 & 0.22 & $\mathrm{~N} / \mathrm{A}^{\mathrm{a}}$ & $\mathrm{N} / \mathrm{A}^{\mathrm{a}}$ & $\mathrm{N} / \mathrm{A}^{\mathrm{a}}$ \\
\hline$\%$ Hg removal & 6.0 & 20.3 & $\mathrm{~N} / \mathrm{A}^{\mathrm{a}}$ & $\mathrm{N} / \mathrm{A}^{\mathrm{a}}$ & $\mathrm{N} / \mathrm{A}^{\mathrm{a}}$ \\
\hline
\end{tabular}

${ }^{\mathrm{a}} \mathrm{N} / \mathrm{A}$ : not applicable.

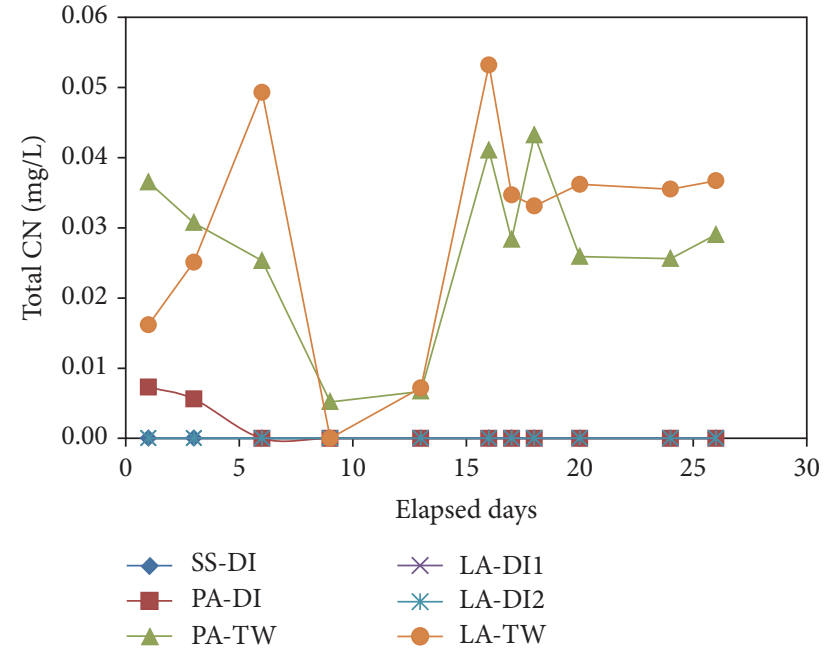

FIgURE 4: Total cyanide $(\mathrm{CN})$ concentrations measured over time for each column.

In the field site, it is reported that almost all of the dissolved mercury in the aquifer pore water is in the form of cyanide complexes and the neutrally charged $\mathrm{Hg}(\mathrm{CN})_{2}$ complex predominates over other dissolved mercury species at the aquifer $\mathrm{pH}$ values. Attenuation of $\mathrm{Hg}$ in the main part of the aquifer is only a minor control on dissolved $\mathrm{Hg}$ concentrations in the aquifer and the predominance of $\mathrm{Hg}$ as a neutrally charged cyanide complex may be responsible for its apparent high mobility in the aquifer. Therefore, the $\mathrm{Hg}$ in the sediment cores for this column experiment, which were drilled down gradient of the tailings, can also be present in the form of cyanide complexes.

As explained in Section 2.3, pumping of influent water was stopped for the duration of 18 days between elapsed days 16 and 17 , to evaluate if $\mathrm{Hg}$ concentration is rebounded due to redissolution/desorption in static conditions. As shown in Figure 3, after the equilibration period, only slight rebound of dissolved $\mathrm{Hg}$ concentration was observed only for PA-TW, showing $\mathrm{Hg}$ concentration of $7.70 \mu \mathrm{g} / \mathrm{L}$ at elapsed day 18 from $0.81 \mu \mathrm{g} / \mathrm{L}$ at elapsed day 17 (there is one day of lag time for sampling that has representative effluent water sample from the column). It is not certain whether or not further rebound could be observed over longer period of static condition.

Based on the Hg content in the solid samples $(0.196 \mathrm{mg} / \mathrm{kg}$ for PA and $0.0287 \mathrm{mg} / \mathrm{kg}$ for LA) and sediment masses and pore volumes in each column, the maximum Hg concentrations expected in water, if all of $\mathrm{Hg}$ is dissolved into pore water, were calculated to be $1.05-1.40 \mathrm{mg} / \mathrm{L}$ for PA and 0.18 $0.20 \mathrm{mg} / \mathrm{L}$ for LA (Table 4). The highest $\mathrm{Hg}$ concentration observed in the effluent of PA was $0.102 \mathrm{mg} / \mathrm{L}$, only $7-10 \%$ of the maximum concentration expected from complete dissolution. The amounts of water passed through the columns between two adjacent sampling events and the effluent $\mathrm{Hg}$ concentrations at each sampling event provide masses of $\mathrm{Hg}$ flushed out between the two sampling events. By summing up the masses of $\mathrm{Hg}$ flushed out for the entire sampling period, $\mathrm{Hg}$ removal by flushing was calculated to be $0.063 \mathrm{mg}$ for PA-DI and $0.227 \mathrm{mg}$ for PA-TW. These values correspond to 6.0 and $20.3 \%$ of removal of $\mathrm{Hg}$ inventory in the sediments of PA-DI and PA-TW, respectively. The results indicate that flushing of aquifer by injecting water, particularly the treated water, can achieve significant amount of $\mathrm{Hg}$ removal from the sediment under the conditions similar to this experiment.

3.2. Total Cyanide (CN). Figure 4 shows the total cyanide (CN) concentrations measured over time for each column. The total CN concentrations at the column effluents were generally low $(0.026-0.053 \mathrm{mg} / \mathrm{L}$ for PA-TW and LA-TW and nondetectable level $(<0.005 \mathrm{mg} / \mathrm{L})$ for the rest of the columns, except for early times in PA-DI). The effluent total $\mathrm{CN}$ concentrations for PA-TW and LA-TW were roughly comparable to the total $\mathrm{CN}$ concentration in the treated water $(0.0231 \mathrm{mg} / \mathrm{L}$, Table 2$)$. It is also possible that some cyanide was released from the sediments. The lower values for two sampling events at elapsed days 9 and 13 could be experimental artifacts. It appears that the total $\mathrm{CN}$ initially present in PA-DI column was flushed out as the deionized source water continued to be supplied to the column.

Cyanide is a strong complexing agent and it may enhance the mobility of many dissolved metals, including $\mathrm{Hg}$, in the tailings pore water. Dissolved mercury cyanide complexes may exist in the forms of $\mathrm{Hg}(\mathrm{CN})_{2}, \mathrm{Hg}(\mathrm{CN})_{3}{ }^{-}$, and $\mathrm{Hg}(\mathrm{CN})_{4}{ }^{2-}$. In the acidic $\mathrm{pH}$ conditions in the tailings, anionic mercury cyanide complexes are adsorbed onto clays, iron and aluminum oxides, and oxyhydroxides due to the positive surface charge of these materials [27, 28]. The dissociation of surface cyanide complexes may occur upon geochemical changes [21, 29], which might be the case for the conditions in the flushing column experiments. The $\mathrm{pH}$ values of the column effluents ( $\mathrm{pH} \sim 4$ for PA and $\sim 5$ to 6 for LA, Figure 5(a)) were in the range where $\mathrm{HCN}$ is the predominant form of free cyanide.

3.3. $p H$, Alkalinity, and Electrical Conductivity (EC). Figure 5(a) shows the effluent $\mathrm{pH}$ values measured over time for 


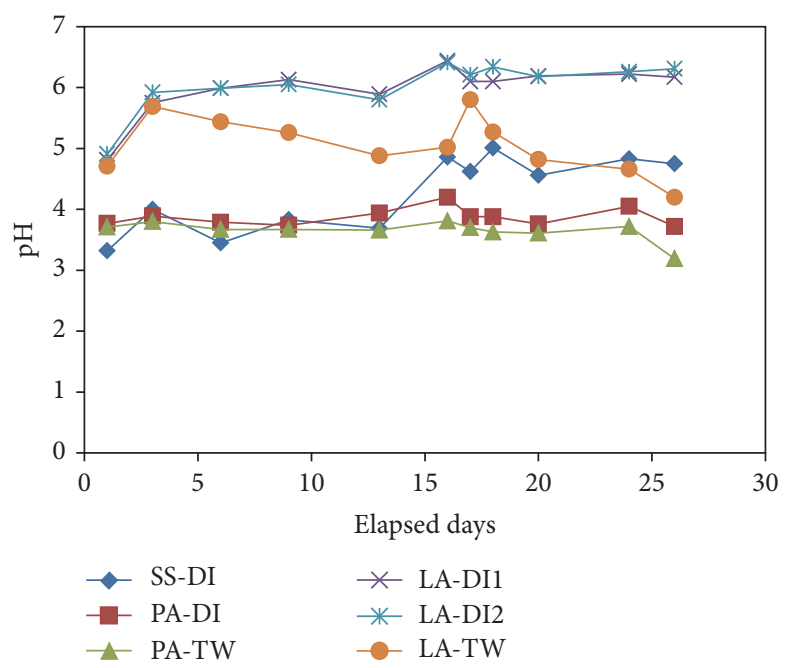

(a)

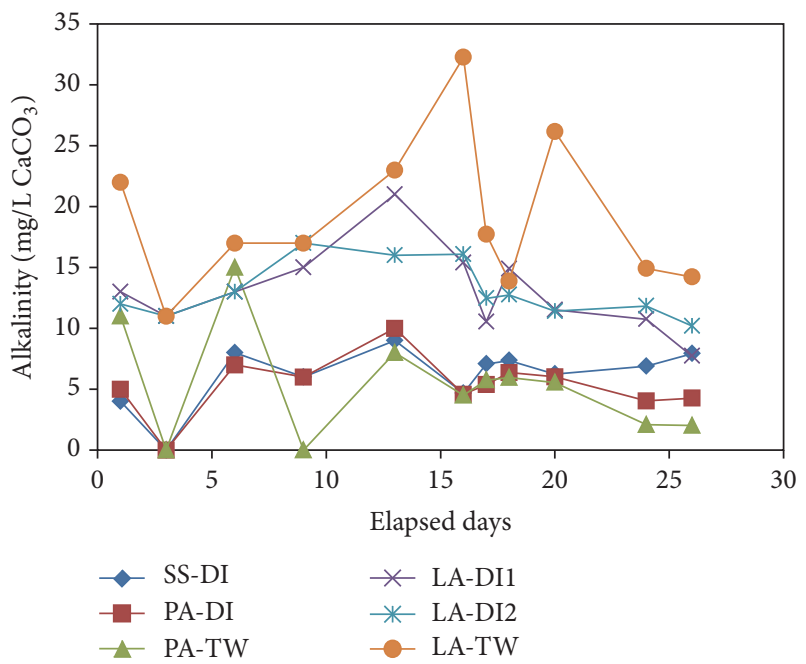

(b)

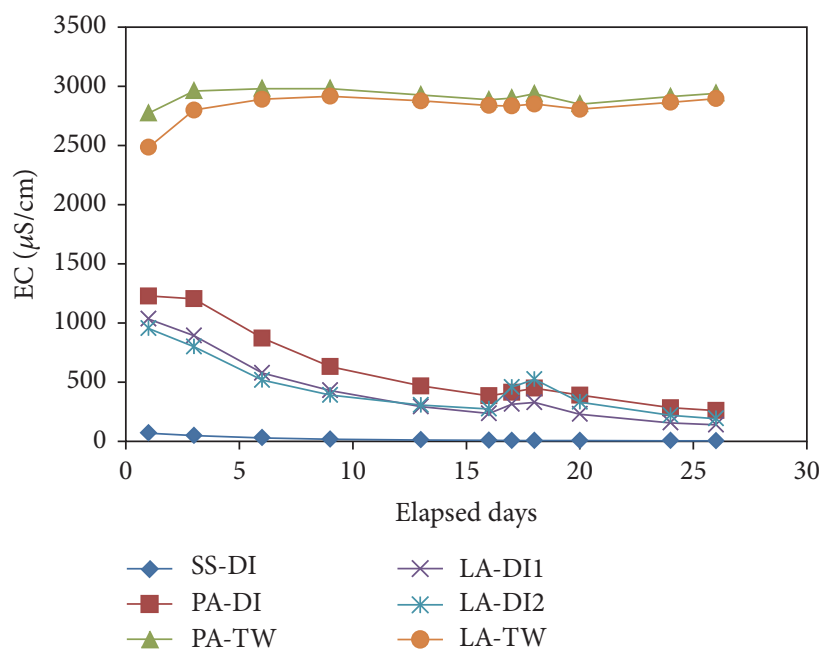

(c)

Figure 5: (a) pH, (b) alkalinity, and (c) EC measured over time for each column.

each column. Generally, higher pH values for LA columns are observed compared to those for PA columns, which is consistent with the paste $\mathrm{pHs}$ for the sediments (4.24 and 6.35 for PA and LA, resp., for 1:2 solid: water, Table 1). This indicates that naturally acidic $\mathrm{pH}$ values are present in the perched aquifer due to occurrences of sulfur mineralization in the area. Gradual decline in $\mathrm{pH}$ observed for LA-TW could be due to dissolution of alumino-silicate minerals in this column (see Figure 7).

It is not certain why $\mathrm{pH}$ for the control column (SS-DI) showed low $\mathrm{pH}(<4)$ until day 16 . One possible cause is the remnant of acidic pore water that was initially present because of acid washing. As explained in Section 2.2, silica sand was washed with $5 \% \mathrm{HNO}_{3}$ solution overnight and rinsed with deionized water. Although the measured $\mathrm{pH}$ for the top water after rinsing was back to normal, some remnant of acidic water might be present in the pore spaces because more silica sand was used for the control column. This potential effect may be minimal for the other columns because only bottom and top $\sim 2.5 \mathrm{~cm}$ ends were filled with silica sand for the other columns, while almost half was filled with silica sand for the control column.

Figure 5(b) shows the total alkalinities measured over time for each column. Alkalinities for PA columns were 4$15 \mathrm{mg} / \mathrm{L}$ as $\mathrm{CaCO}_{3}$, while they were $8-32 \mathrm{mg} / \mathrm{L}$ as $\mathrm{CaCO}_{3}$ for LA columns. For comparison, the influent TW water had alkalinity of $14-17 \mathrm{mg} / \mathrm{L}$ as $\mathrm{CaCO}_{3}$. The higher alkalinity values for LA columns compared to PA columns are probably due to dissolution of carbonate minerals in LA. The Ca contents in the sediments were 1060 and $2430 \mathrm{mg} / \mathrm{kg}$ for PA and LA, respectively, and Mg contents were 2610 and $3010 \mathrm{mg} / \mathrm{kg}$ for PA and LA, respectively, supporting this explanation. This is consistent with the dissolved $\mathrm{Ca}$ and $\mathrm{Mg}$ concentrations at the effluents (see Figures 7(a) and 7(b)) and also consistent with the effluent $\mathrm{pH}$ values (Figure 5(a)).

The trends of EC (Figure 5(c)) show that dissolved components in the columns receiving deionized water are generally flushed out, while the columns receiving treated 


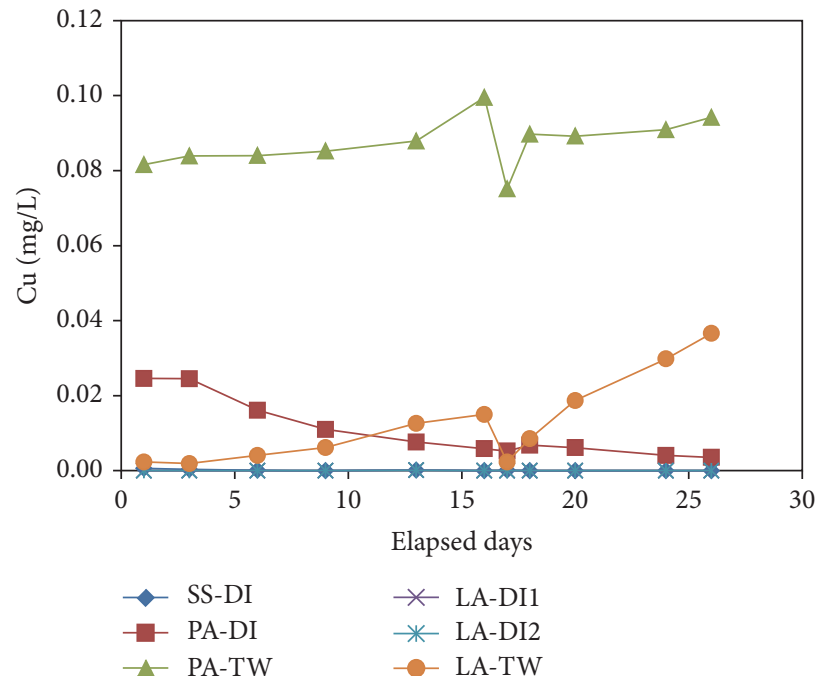

(a)

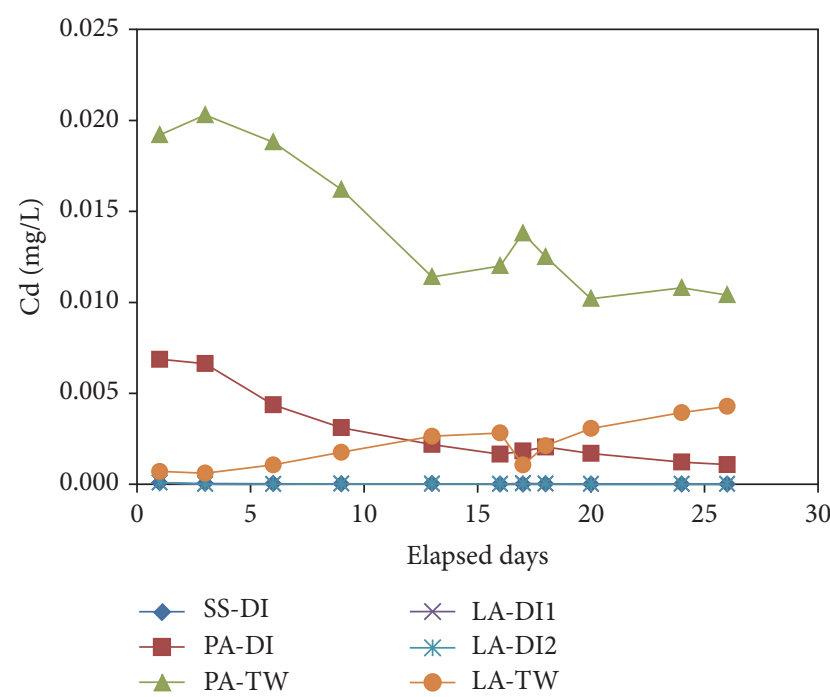

(c)

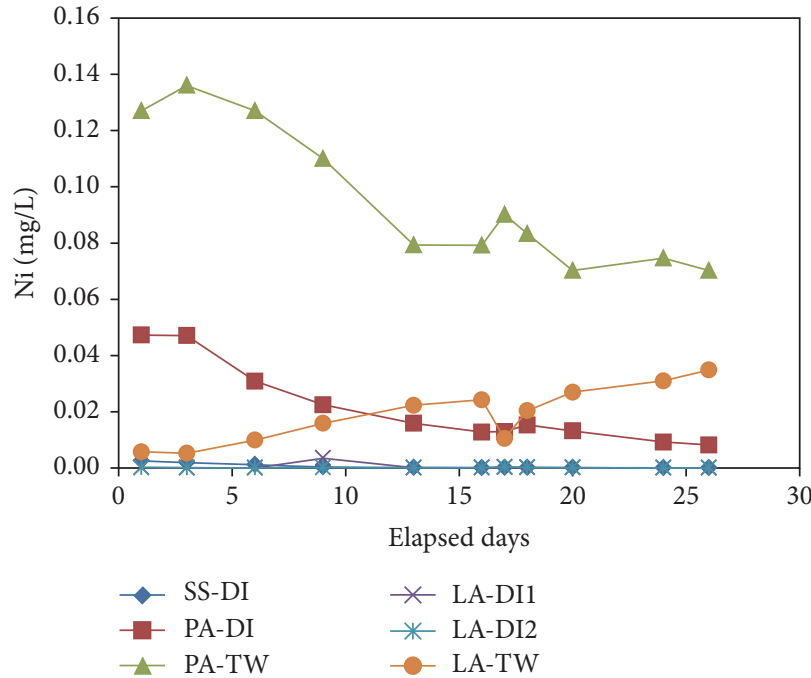

(e)

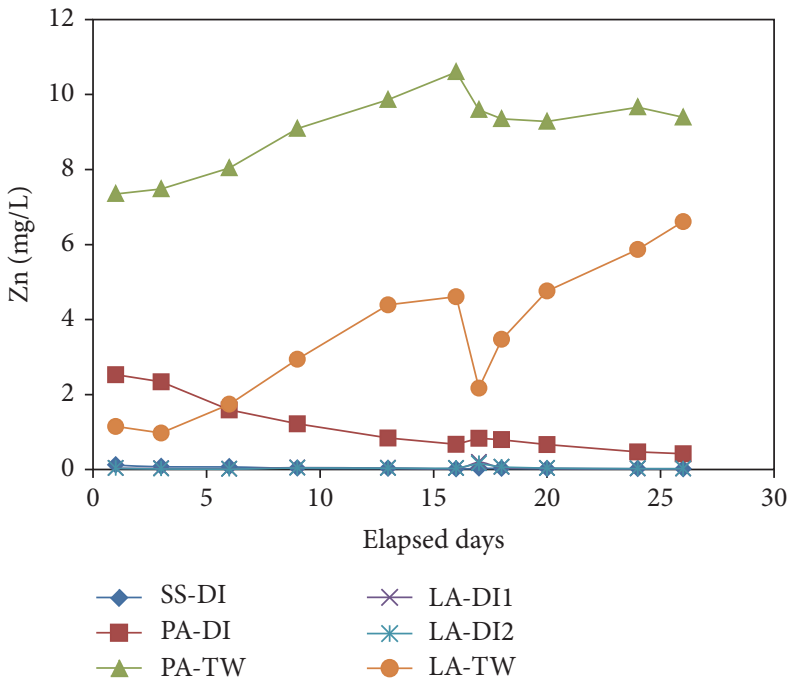

(b)

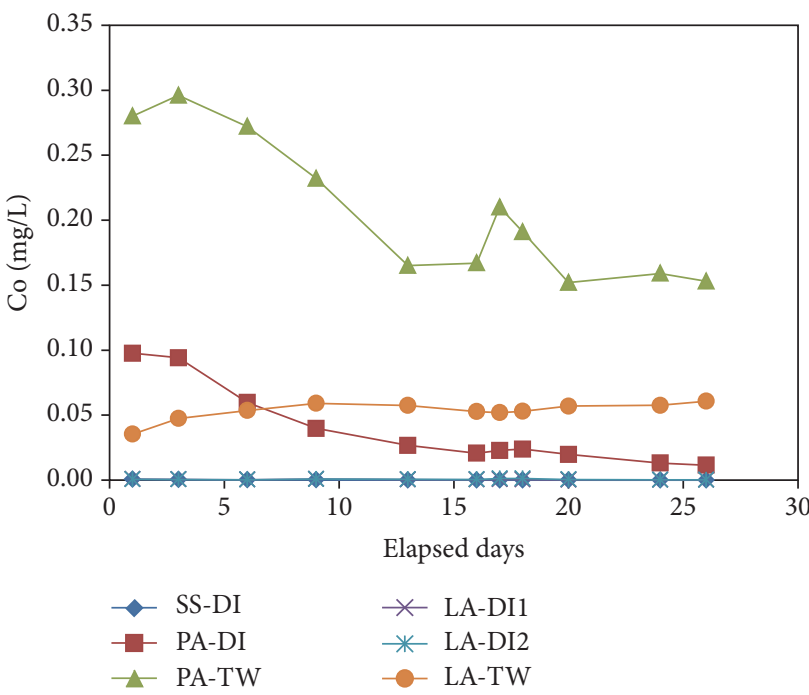

(d)

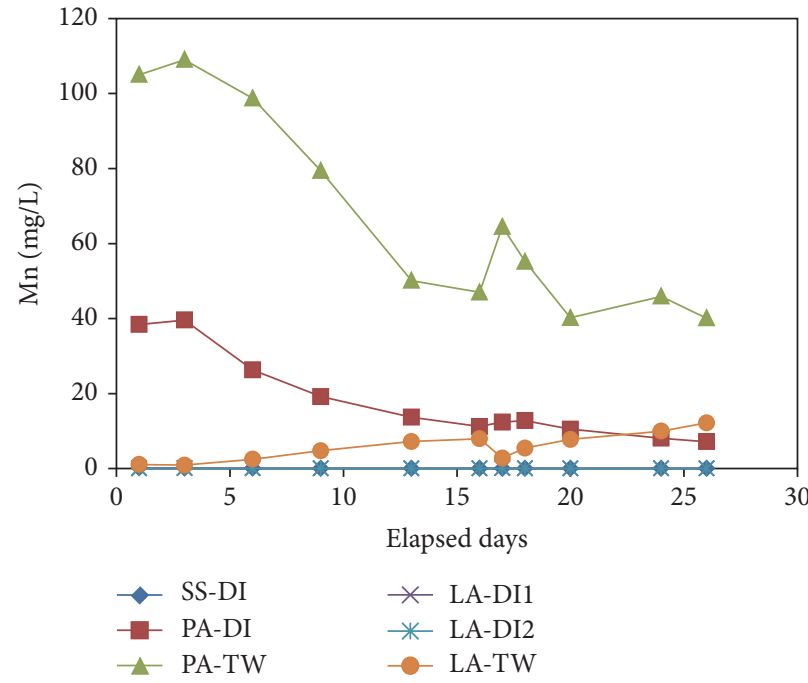

(f)

Figure 6: Continued. 


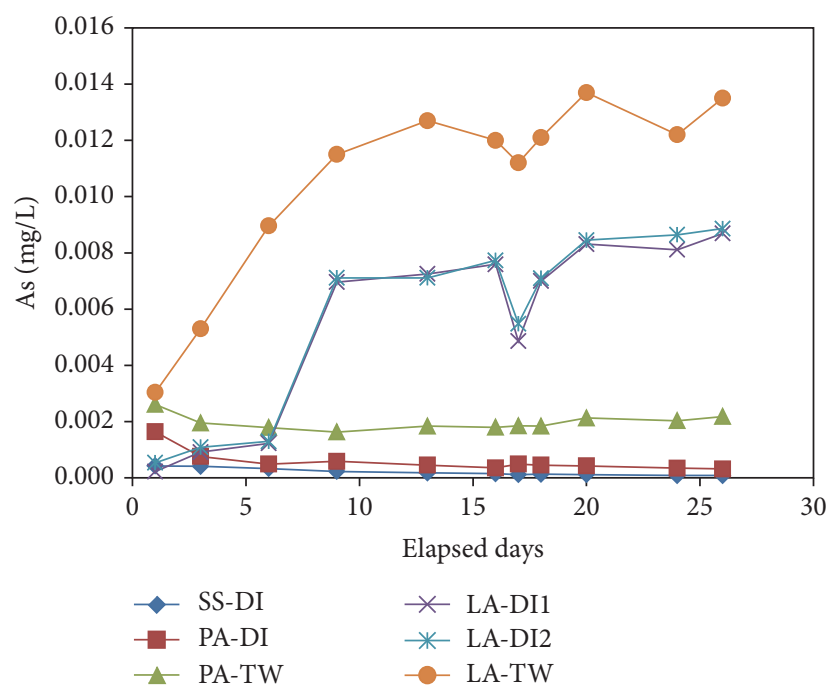

(g)

Figure 6: (a) Cu, (b) Zn, (c) Cd, (d) Co, (e) Ni, (f) Mn, and (g) As concentrations measured over time for each column.

water show more or less consistent EC over the course of the experiments, primarily due to already high total dissolved solids (TDS) in the treated water.

3.4. Other Metals and Cations. Considering similar complexation behaviors of $\mathrm{Hg}, \mathrm{Cu}$, and $\mathrm{Zn}$ with cyanide, it was expected that the trends of $\mathrm{Cu}$ and $\mathrm{Zn}$ concentrations are similar to those of $\mathrm{Hg}$. It was the case for the columns receiving deionized water (Figures 6(a) and 6(b)); however, for the columns receiving the treated water, $\mathrm{Cu}$ and $\mathrm{Zn}$ concentrations generally increased as the experiment progressed, except for the elapsed days 16 and 17 when the static conditions were tested. This may be partly due to the fact that the sediments contained higher $\mathrm{Cu}$ and $\mathrm{Zn}$ contents $(\mathrm{Cu}$ content of 85.9 and $52.9 \mathrm{mg} / \mathrm{kg}$ and $\mathrm{Zn}$ content of 358 and $407 \mathrm{mg} / \mathrm{kg}$ for PA and LA, resp.) relative to $\mathrm{Hg}(0.196 \mathrm{mg} / \mathrm{kg}$ for PA and $0.0287 \mathrm{mg} / \mathrm{kg}$ for LA). While complexation of $\mathrm{Cu}$ and $\mathrm{Zn}$ with cyanide could explain the elevated $\mathrm{Cu}$ and Zn concentrations for PA-TW and LA-TW, the total cyanide concentrations at the effluents were low $(0.026-0.053 \mathrm{mg} / \mathrm{L}$ for PA-TW and LA-TW), suggesting the presence of other complexing agents in the treated water other than cyanide, similar to the case for $\mathrm{Hg}$.

The trends for $\mathrm{Cd}, \mathrm{Co}, \mathrm{Ni}$, and $\mathrm{Mn}$ (Figures 6(c)6(f)) were similar to those for $\mathrm{Cu}$ and $\mathrm{Zn}$; however, PATW showed general decreases in concentrations as the experiment progressed, suggesting flushing of these elements out of the sediments instead of increases in concentrations due to dissolution/desorption or complexation. Dissolved As concentrations at the column effluents were higher for LA than for PA (Figure 6(g)), although the solid sample analyses showed higher value for PA than LA (282 and $178 \mathrm{mg} / \mathrm{kg}$ for PA and LA, resp.). Dissolved As, which is not complexed with cyanide, is attenuated due to adsorption onto and coprecipitation with secondary metal oxides and (oxy)hydroxides under neutral or acidic $\mathrm{pH}$ conditions [30].
Thus, the release of As in LA columns could be related to desorption of As associated with dissolution of oxides and (oxy)hydroxides that was previously precipitated in this sediment. It may also be caused by reductive dissolution of As-bearing oxyhydroxides such as ferrihydrite [31].

The effluent $\mathrm{Ca}$ and $\mathrm{Mg}$ concentrations (Figures 7(a) and $7(b)$ ) suggest that dissolution of carbonate minerals could be the source of $\mathrm{Ca}$ and $\mathrm{Mg}$ in most of the columns, while flushing is predominant in PA-DI. The releases of $\mathrm{Al}, \mathrm{K}, \mathrm{Na}$, and $\mathrm{Si}$ (Figures 7(c)-7(f)) may indicate dissolution of aluminosilicate minerals, such as feldspar, in the sediments. It is shown that the aquifer materials consist primarily of quartz and feldspar, with lesser amounts of clay, mica, and iron oxides and oxyhydroxides. The trends for Al (Figure 7(c)) are different from other elements (K, Na, and Si, Figures $7(\mathrm{~d})-$ $7(\mathrm{f})$ ), indicating the precipitation and dissolution of other Alcontaining minerals, such as amorphous $\mathrm{Al}(\mathrm{OH})_{3}$, gibbsite, and alunite, or Al-complexation may also be controlling $\mathrm{Al}$ concentrations.

\section{Conclusions}

The column experiments evaluated removal of $\mathrm{Hg}$ from the aquifer sediments using potential flushing waters including the treated water from the water treatment plant and deionized water. The results showed that columns packed with perched aquifer material had flushing of $\mathrm{Hg}$, with the general decline of effluent $\mathrm{Hg}$ concentrations over time (from $0.05-0.1 \mathrm{mg} / \mathrm{L}$ in the beginning of the experiment to $0.0001-$ $0.003 \mathrm{mg} / \mathrm{L}$ at the completion of the experiment). About 5$20 \% \mathrm{Hg}$ had been flushed out from the sediment during the experiments (about 10 pore volumes), while most of flushing occurred within 5 pore volumes.

The results suggest that flushing of $\mathrm{Hg}$ in the aquifer materials by injection of water has the potential to be effective at reducing $\mathrm{Hg}$ concentrations in the aquifer. Removal of 


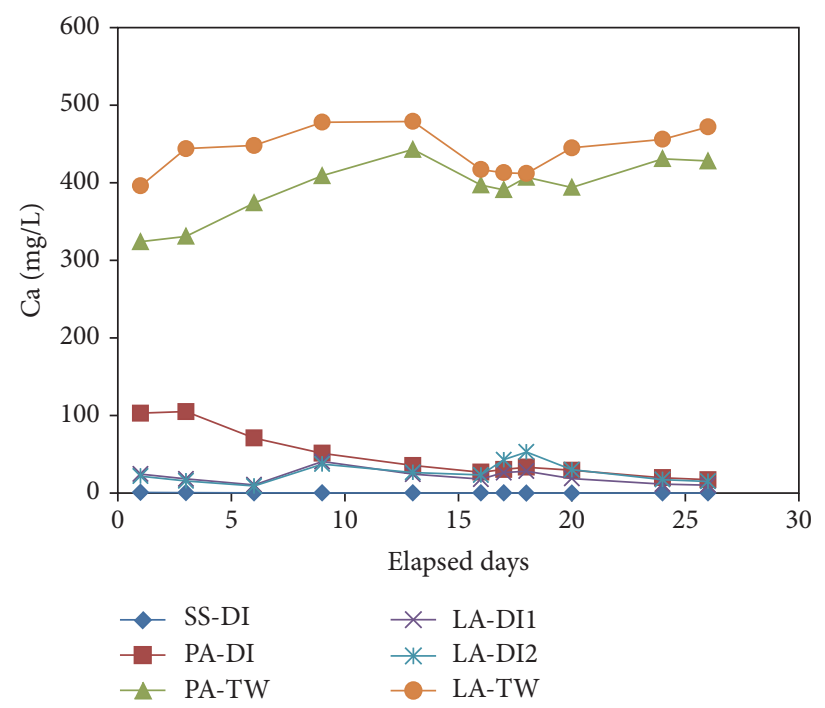

(a)

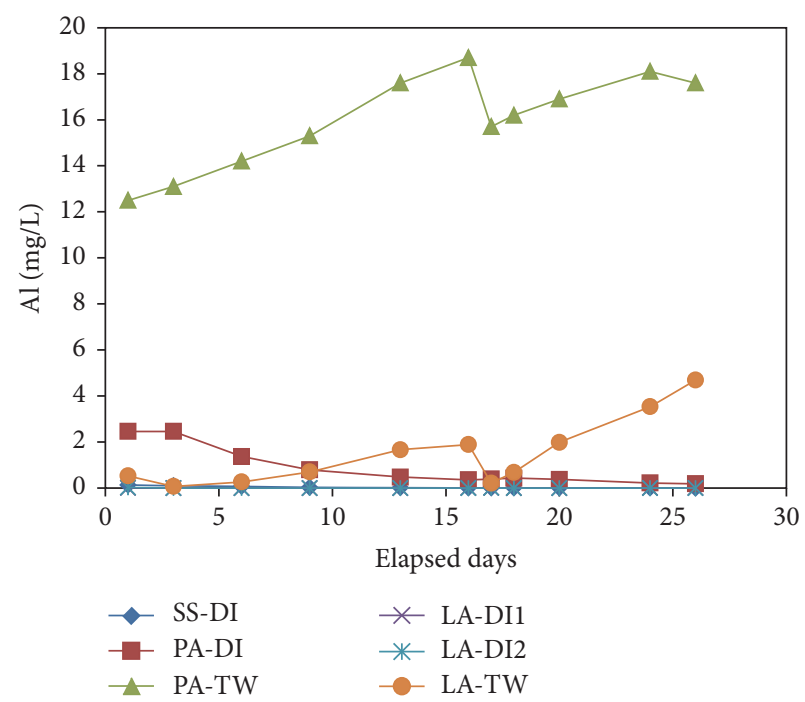

(c)

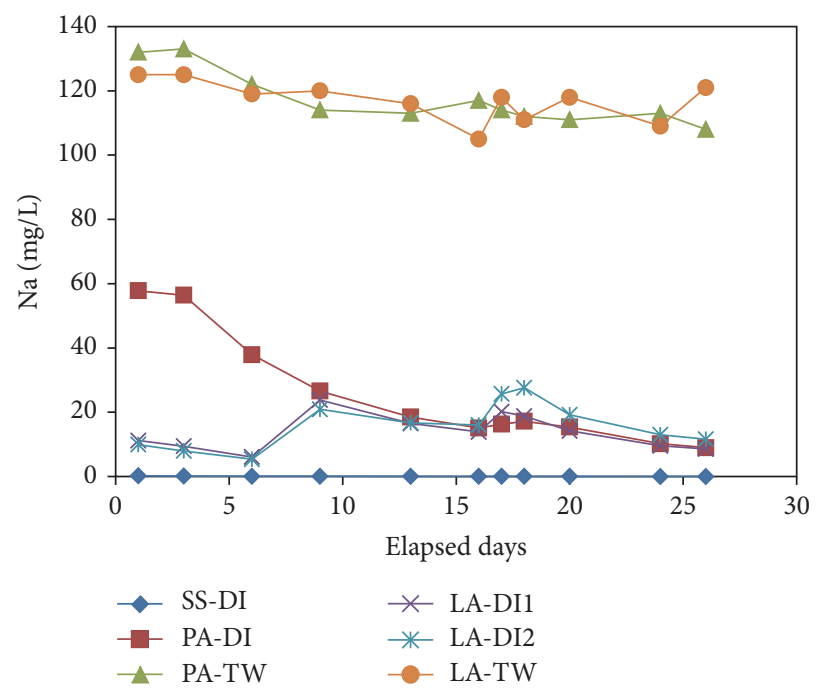

(e)

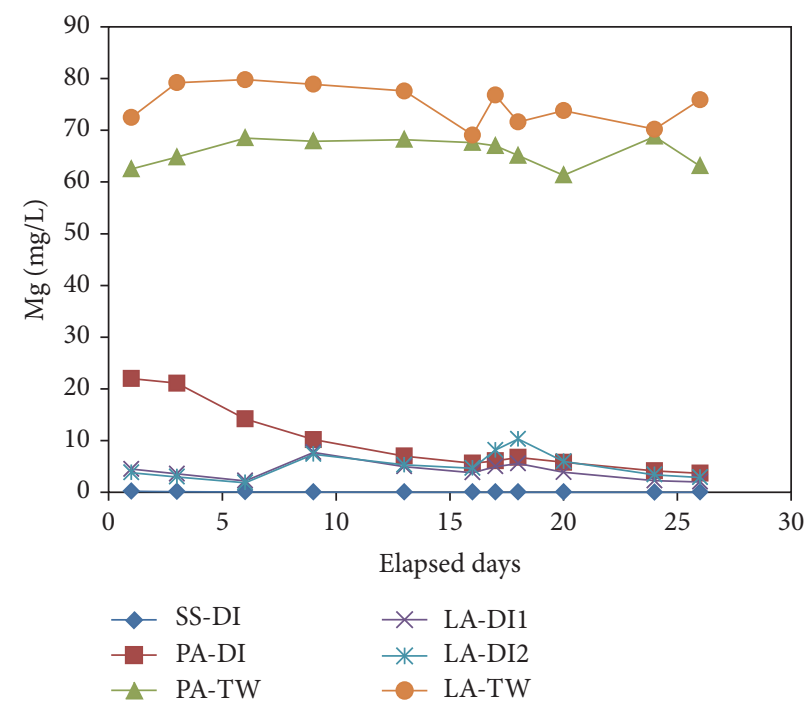

(b)

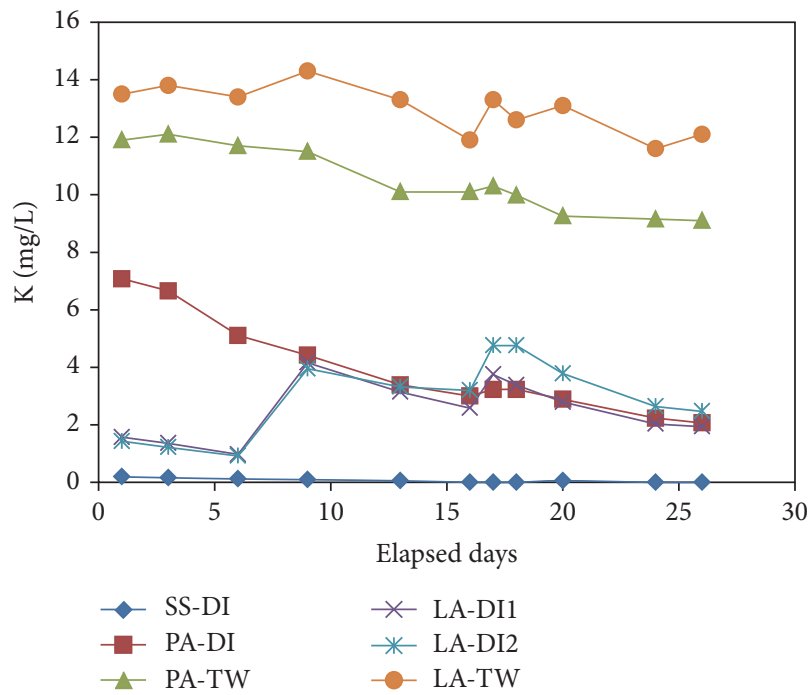

(d)

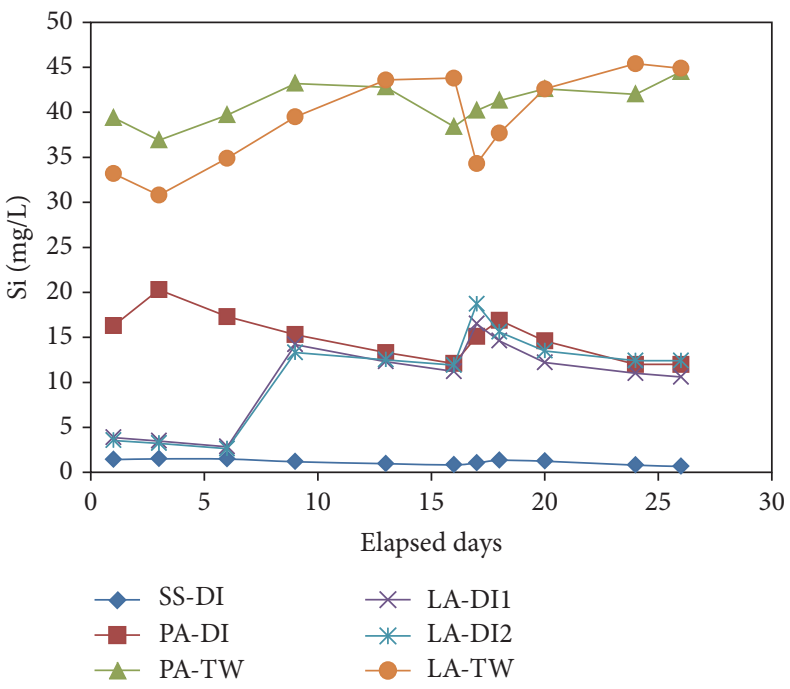

(f)

Figure 7: (a) Ca, (b) Mg, (c) Al, (d) K, (e) Na, and (f) Si concentrations measured over time for each column. 
up to $20 \%$ of the $\mathrm{Hg}$ inventory in the sediment could be achievable. The results also indicate that the treated water from the water treatment plant is a reasonable flushing solution, probably due to complexing agents contained in the treated water.

It should be noted, however, that the field condition can be different from the experimental conditions. For example, the flow velocity in the column was $6.5-7.3 \mathrm{~cm} /$ day, while the groundwater velocity during the injection could be as high as $2 \mathrm{~m} /$ day in the field. The difference in contact time may affect dissolved $\mathrm{Hg}$ concentrations in the flushed water. Also, the actual field injection may deliver up to 3 pore volumes for a period of 3 months, indicating that extended period of injection may be required to obtain desirable results.

The solid-phase analyses, as well as the results of the column experiments, showed that the perched aquifer contained more $\mathrm{Hg}$ compared to lower aquifer and only the perched aquifer showed flushing of $\mathrm{Hg}$ out of the sediment. Perched aquifer material has more $\mathrm{Hg}$ than lower aquifer material $(0.196 \mathrm{mg} / \mathrm{kg}$ versus $0.0287 \mathrm{mg} / \mathrm{kg})$. This result indicates heterogeneity of aquifer geochemistry that needs to be considered in the field practice.

Possibility of redissolution/desorption of $\mathrm{Hg}$ after static conditions (for the duration of 18 days) was tested, showing only slight rebound of $\mathrm{Hg}$ concentrations. However, because of the limited time frame for this study, it is not certain whether or not further rebound could be observed over longer periods of static conditions. Additional testing for longer periods of static conditions could confirm this behavior.

As shown in the experiments, complexation of $\mathrm{Hg}$ with complexing agents can enhance removal of $\mathrm{Hg}$ by flushing. Testing of water containing added complexing agents, such as ethylenediaminetetraacetic acid (EDTA) and ethylenediamine- $N, N^{\prime}$-disuccinic acid (EDDS), a biodegradable alternative to EDTA, can be used to evaluate the enhanced removal of $\mathrm{Hg}$ by complexation and its potential benefits.

\section{Competing Interests}

The author declares that they have no competing interests.

\section{Acknowledgments}

Funding for this research was provided by the Basic Science Research Program through the National Research Foundation of Korea (NRF) funded by the Ministry of Education (NRF-2014R1A1A2058040) and by the "R\&D Project on Environmental Management of Geologic $\mathrm{CO}_{2}$ Storage" from the KEITI (Project no. 2014001810003).

\section{References}

[1] W. Salomons, "Environmental impact of metals derived from mining activities: processes, predictions, prevention," Journal of Geochemical Exploration, vol. 52, no. 1-2, pp. 5-23, 1995.
[2] J. J. Rytuba, "Mercury from mineral deposits and potential environmental impact," Environmental Geology, vol. 43, no. 3, pp. 326-338, 2003.

[3] United Nations Environmental Programme, "Technical and economical criteria for processing mercury-containing tailings," Final Report, nited Nations Environmental Programme, Division of Technology, Industry, and Economics, 2010.

[4] S. C. Brooks and G. R. Southworth, "History of mercury use and environmental contamination at the Oak Ridge Y-12 Plant," Environmental Pollution, vol. 159, no. 1, pp. 219-228, 2011.

[5] D. Watson, C. Miller, B. Lester et al., "Mercury source zone identification using soil vapor sampling and analysis," Frontiers of Environmental Science and Engineering, vol. 9, no. 4, pp. 596604, 2015.

[6] J.-C. J. Bonzongo, B. W. Nemer, and W. B. Lyons, "Hydrological controls on water chemistry and mercury biotransformation in a closed river system: the Carson River, Nevada," Applied Geochemistry, vol. 21, no. 11, pp. 1999-2009, 2006.

[7] M. M. Matlock, B. S. Howerton, M. A. van Aelstyn, F. L. Nordstrom, and D. A. Atwood, "Advanced mercury removal from gold leachate solutions prior to gold and silver extraction: a field study from an active gold mine in Peru," Environmental Science and Technology, vol. 36, no. 7, pp. 1636-1639, 2002.

[8] A. Tadjeddine and A. Le Rille, "Adsorption of cyanide on gold single crystal investigated by in situ visible-infrared difference frequency generation," Electrochimica Acta, vol. 45, no. 4-5, pp. 601-609, 1999.

[9] M. A. Rawashdeh-Omary, M. A. Omary, and H. H. Patterson, "Oligomerization of $\mathrm{Au}(\mathrm{CN})_{2}{ }^{-}$and $\mathrm{Ag}(\mathrm{CN})_{2}{ }^{-}$ions in solution via ground-state aurophilic and argentophilic bonding," Journal of the American Chemical Society, vol. 122, no. 42, pp. 1037110380, 2000.

[10] K. L. Rees and J. S. J. van Deventer, "The role of metal-cyanide species in leaching gold from a copper concentrate," Minerals Engineering, vol. 12, no. 8, pp. 877-892, 1999.

[11] C. S. Kim, G. E. Brown Jr., and J. J. Rytuba, "Characterization and speciation of mercury-bearing mine wastes using X-ray absorption spectroscopy," The Science of the Total Environment, vol. 261, no. 1-3, pp. 157-168, 2000.

[12] C. S. Kim, J. J. Rytuba, and G. E. Brown Jr., "Geological and anthropogenic factors influencing mercury speciation in mine wastes: an EXAFS spectroscopy study," Applied Geochemistry, vol. 19, no. 3, pp. 379-393, 2004.

[13] T. A. Al, M. I. Leybourne, A. C. Maprani et al., "Effects of acid-sulfate weathering and cyanide-containing gold tailings on the transport and fate of mercury and other metals in Gossan Creek: Murray Brook mine, New Brunswick, Canada," Applied Geochemistry, vol. 21, no. 11, pp. 1969-1985, 2006.

[14] G. A. Gill and K. W. Bruland, "Mercury speciation in surface freshwater systems in California and other areas," Environmental Science and Technology, vol. 24, no. 9, pp. 1392-1400, 1990.

[15] A. J. Slowey, S. B. Johnson, J. J. Rytuba, and G. E. Brown Jr., "Role of organic acids in promoting colloidal transport of mercury from mine tailings," Environmental Science and Technology, vol. 39, no. 20, pp. 7869-7874, 2005.

[16] J. J. Rytuba, "Mercury mine drainage and processes that control its environmental impact," The Science of the Total Environment, vol. 260, no. 1-3, pp. 57-71, 2000.

[17] C. G. Weisener, K. S. Sale, D. J. A. Smyth, and D. W. Blowes, "Field column study using zerovalent iron for mercury removal 
from contaminated groundwater," Environmental Science and Technology, vol. 39, no. 16, pp. 6306-6312, 2005.

[18] B. D. Gibson, C. J. Ptacek, M. B. J. Lindsay, and D. W. Blowes, "Examining mechanisms of groundwater $\mathrm{Hg}(\mathrm{II})$ treatment by reactive materials: an EXAFS study," Environmental Science and Technology, vol. 45, no. 24, pp. 10415-10421, 2011.

[19] J. D. Vernon and J.-C. J. Bonzongo, "Volatilization and sorption of dissolved mercury by metallic iron of different particle sizes: implications for treatment of mercury contaminated water effluents," Journal of Hazardous Materials, vol. 276, pp. 408-414, 2014.

[20] P. Liu, C. J. Ptacek, D. W. Blowes, and R. C. Landis, "Mechanisms of mercury removal by biochars produced from different feedstocks determined using X-ray absorption spectroscopy," Journal of Hazardous Materials, vol. 308, pp. 233-242, 2016.

[21] S. A. Shaw, T. A. Al, and K. T. B. MacQuarrie, "Mercury mobility in unsaturated gold mine tailings, Murray Brook mine, New Brunswick, Canada," Applied Geochemistry, vol. 21, no. 11, pp. 1986-1998, 2006.

[22] A. Navarro, E. Cardellach, and M. Corbella, "Mercury mobility in mine waste from $\mathrm{Hg}$-mining areas in Almería, Andalusia (Se Spain)," Journal of Geochemical Exploration, vol. 101, no. 3, pp. 236-246, 2009.

[23] R. H. Loeppert and D. L. Suarez, "Gravimetric method for loss of carbon dioxide," in Methods of Soil Analysis: Part 3. Chemical Methods, J. M. Bartels and J. M. Bigham, Eds., Book Series No. 5, ASA and SSSA, Madison, Wis, USA, 3rd edition, 1996.

[24] C. H. Lamborg, C.-M. Tseng, W. F. Fitzgerald, P. H. Balcom, and C. R. Hammerschmidt, "Determination of the mercury complexation characteristics of dissolved organic matter in natural waters with 'reducible Hg' titrations,' Environmental Science and Technology, vol. 37, no. 15, pp. 3316-3322, 2003.

[25] C. L. Miller, L. Liang, and B. Gu, "Competitive ligand exchange reveals time dependant changes in the reactivity of $\mathrm{Hg}$ dissolved organic matter complexes," Environmental Chemistry, vol. 9, no. 6, pp. 495-501, 2012.

[26] C. S. Kim, J. J. Rytuba, and G. E. Brown Jr., "EXAFS study of mercury(II) sorption to Fe- and Al-(hydr)oxides: II. Effects of chloride and sulfate," Journal of Colloid and Interface Science, vol. 270, no. 1, pp. 9-20, 2004.

[27] A. Smith and T. Mudder, The Chemistry and Treatment of Cyanidation Wastes, Mining Journal Books Limited, London, UK, 1991.

[28] T. Rennert and T. Mansfeldt, "Sorption of iron-cyanide complexes in soils," Soil Science Society of America Journal, vol. 66, no. 2, pp. 437-444, 2002.

[29] G. J. Zagury, K. Oudjehani, and L. Deschênes, "Characterization and availability of cyanide in solid mine tailings from gold extraction plants," Science of the Total Environment, vol. 320, no. 2-3, pp. 211-224, 2004.

[30] P. L. Smedley and D. G. Kinniburgh, "A review of the source, behaviour and distribution of arsenic in natural waters," Applied Geochemistry, vol. 17, no. 5, pp. 517-568, 2002.

[31] J. J. Erbs, T. S. Berquó, B. C. Reinsch, G. V. Lowry, S. K. Banerjee, and R. L. Penn, "Reductive dissolution of arsenicbearing ferrihydrite," Geochimica et Cosmochimica Acta, vol. 74, no. 12, pp. 3382-3395, 2010. 

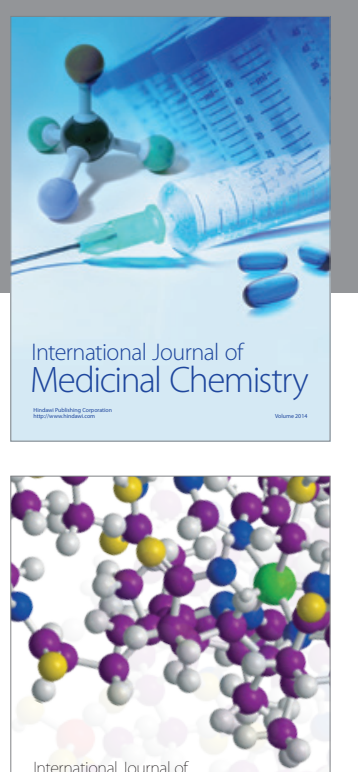

Carbohydrate Chemistry

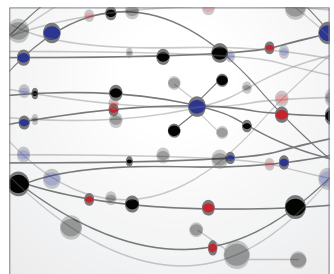

The Scientific World Journal
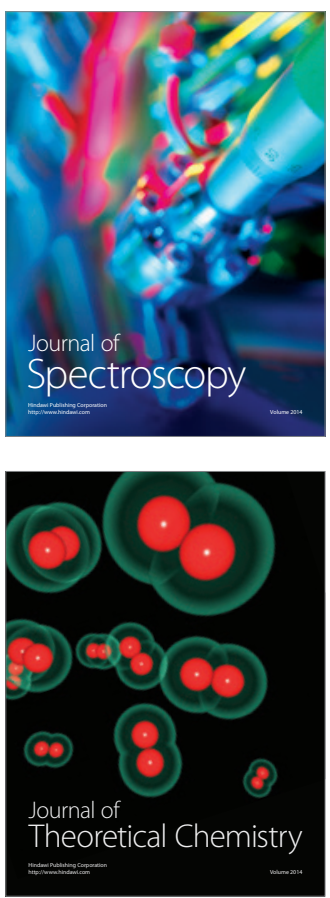
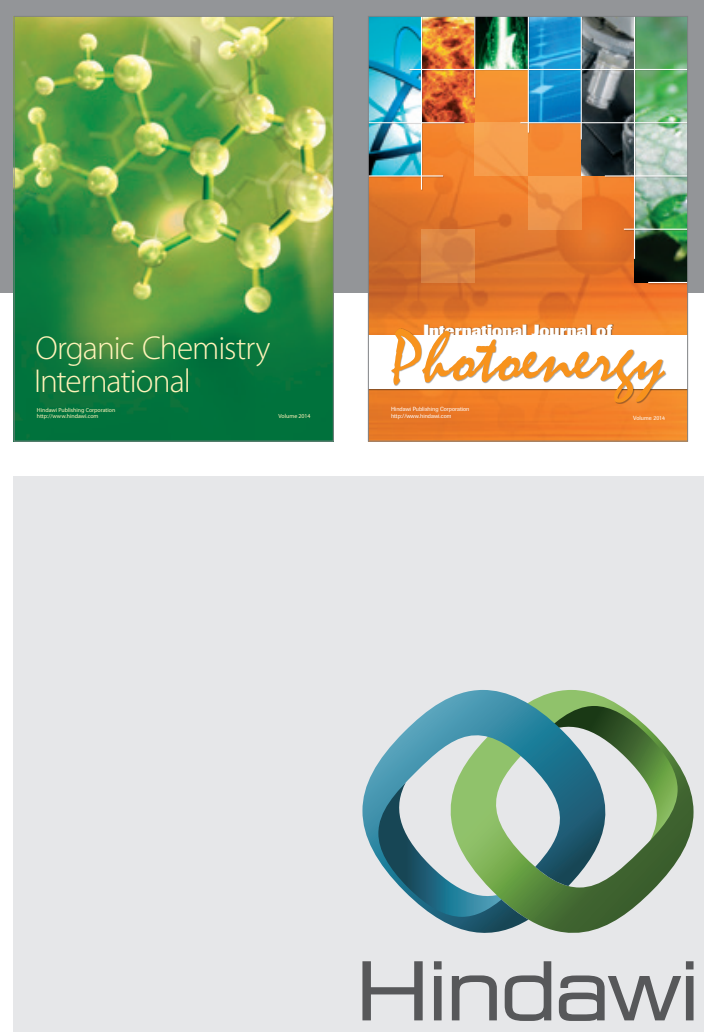

Submit your manuscripts at

http://www.hindawi.com

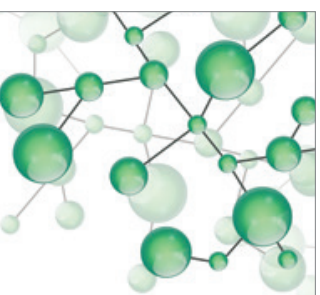

International Journal of

Inorganic Chemistry

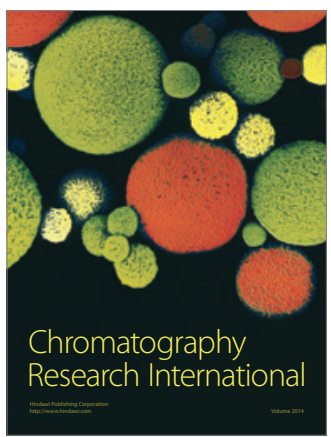

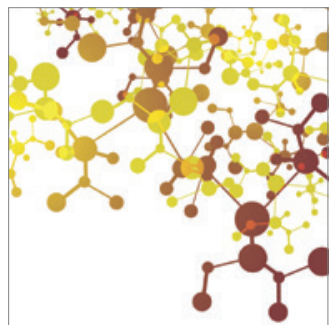

Applied Chemistry
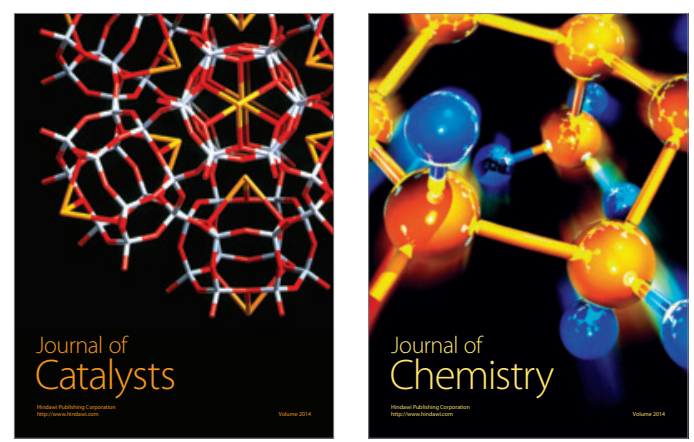
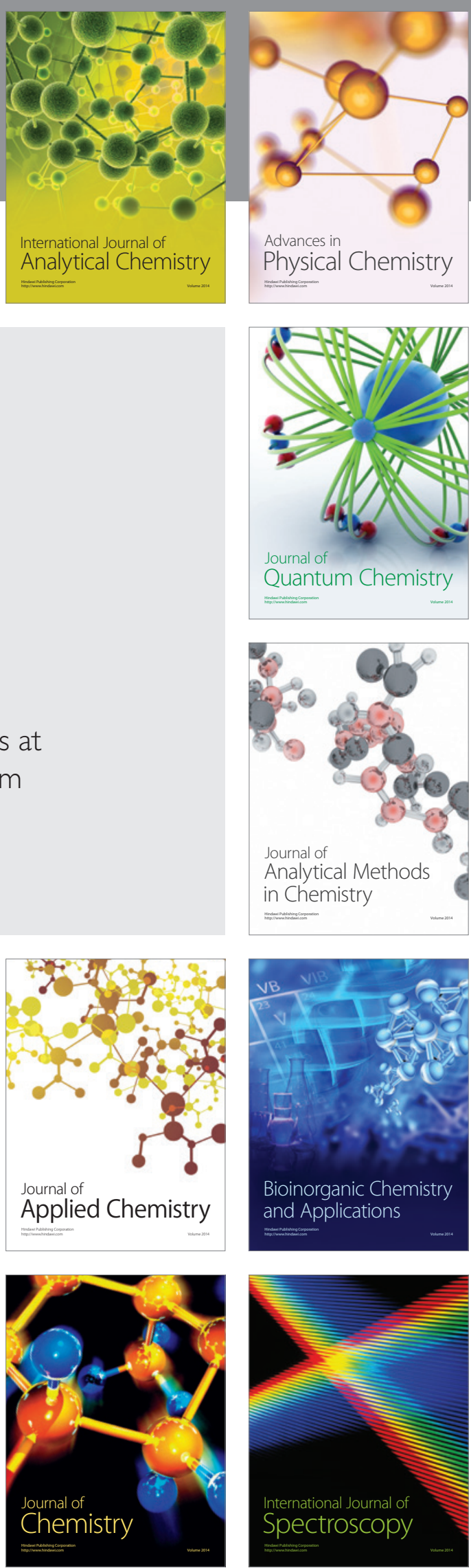